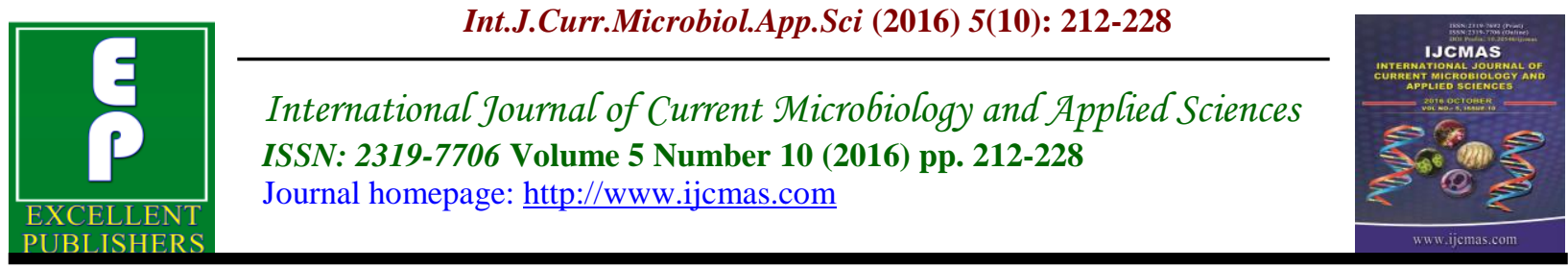

Original Research Article

http://dx.doi.org/10.20546/ijcmas.2016.510.023

\title{
Antibrowning Activity of Bioactive Peptides from Lab-Cultured Skim Milk Hydrolysate
}

\author{
Maryam A.S. Abubakr* \\ Faculty of Science, Zawia University, Libya \\ *Corresponding author
}

\section{A B S T R A C T}

Keywords

Antibrowning activity, Antioxidative activity, Skim milk hydrolysate (SMH), Bioactive peptides.

\begin{tabular}{l}
\hline Article Info \\
\hline Accepted: \\
12 September 2016 \\
Available Online: \\
10 October 2016
\end{tabular}

The application of antibrowning agents is one of the most effective methods for controlling the browning reaction in fruits and vegetables. Therefore, in this study skim milk hydrolysate (SMH) at different concentrations were tested for antibrowning reaction of fruits and vegetables compared with ascorbic acid and citric acid. Fresh Chinese pear and potatoes slices were treated with distilled water (as control), ascorbic acid (AA), citric acid (CA), SMH- L. plantarum 1 (SMH1), SMH- Ln. mesenteroides (SMH2) and combining SMH- L. plantarum 1+ SMHLn. mesenteroides (SMH1+SMH2) at different concentrations $(1,2,3$ and $4 \% \mathrm{w} / \mathrm{v})$ and dipped for $5 \mathrm{~min}$. Then all slices were placed in Petri dishes and exposed to air at room temperature for $0,3,6,12$ and $24 \mathrm{~min}$. The degree of color $\left(L^{*}, \mathrm{a}^{*}, \mathrm{~b}^{*}\right)$, browning index (BI) and total phenolic content (TPC) of the samples were evaluated. The results indicate that the slices of Chinese pear and potato treated with combining SMH1+SMH2 inhibited browning reaction comparable to AA as shown by reduction of TPC. It can be concluded that we found new antibrowning agents from natural source to achieve greater inhibition of browning like as ascorbic acid and citric acid. That would be useful in the formulation of functional foods.

\section{Introduction}

The market for fresh-cut fruit salads and vegetables is expanding rapidly as a consequence of increasing consumer demand for healthy eating, convenience and their fresh-like character (Buckley et al., 2007; Gorny, 2003). The International Fresh-cut Produce Association defines freshcut products as fruits or vegetables that have been trimmed and/or peeled and/or cut into a $100 \%$ usable product that is bagged or prepacked to offer the consumer high nutrition, convenience and flavor while still maintaining its freshness (Garrett, 2002). Since minimal processing results in quality deterioration associated with water loss, softening, microbial contamination, increased respiration and ethylene, and cutsurface browning, minimally processed products become more perishable (Rolle and Chism, 1987; Lee et al., 2003). Slowing or preventing the enzymatic browning of sliced fruit is a continuing problem for the 
processors of fresh-cut fruit. Browning is due to many factors, including cell disruption and the release of polyphenol oxidases (PPOs; Shapton and Shapton, 1998; Garcia and Barret, 2002; MartìnBelloso et al., 2006).

Browning is the main physiological disorder that impairs sensory properties and discourages consumer purchase of fresh-cut fruits. Enzymatic browning reactions in fruits are primarily catalyzed by polyphenol oxidase (PPO) in the presence of oxygen (Martinez and Whitaker, 1995). Extensive research has been focused on control of browning in fresh-cut fruits and several approaches to browning inhibition have been explored. Browning in fruits increases after being cut damaged or stored. Many reports have attempted to establish a relationship between the degree of browning and the phenolic content and enzymatic activity of apples (Vamos-Vigyazo et al., 1976; Klein, 1987; Jeong et al., 2008) and banana (Apintanapong et al., 2007). Thus browning in cut fruits and vegetables is mainly related to polyphenol oxidase (PPO) activity which, in the presence of $\mathrm{O}_{2}$, converts phenolic compounds in fruits and vegetables into dark colored pigments (Burda et al., 1990; Amiot et al., 1992; Suttirak and Supranee, 2010).

Enzymatic browning is a significant problem in a number of fruits and vegetables such as strawberry (Chisari et al., 2007), grape (Munoz et al., 2004), potato (Lee and Park, 2007), and lettuce (Gawlik-Dziki et al., 2007). The discoloration in fruits and vegetables by enzymatic browning, resulting from conversion of phenolic compounds to o-quinones which subsequently polymerize to be a brown or dark pigment. The enzymes involved in these processes are PPO and peroxidase (POD) (Jiang et al., 2004), since PPO and POD are the main enzymes involved in the phenolic oxidation of many fruits and vegetables. Phenolic compounds are a group of chemical substances in plants, which play an important role during enzymatic browning because they are substrates for the browning enzymes. The phenolics are normally complex organic substances, which contain more than one phenolic group. Polyphenolics can be divided into many different subcategories, such as flavonoids and non-flavonoid components.

Application of antibrowning agents is a popular approach for retarding enzymatic browning in fresh-cut fruits and vegetables. Surface treatments by dipping fresh-cut products in the appropriate antibrowning agents can effectively help to delay discoloration. Nature identical antibrowning agents are a favorite group because they are generally recognized as safe (GRAS) status and are non-toxic.

Extensive literature on inhibitors of browning in fresh-cut fruits include using ascorbic acid (AA) (Gorny et al., 2002), citric acid (CA) (Jiang et al., 2004), or their derivatives (Moline et al., 1999) and some sulfur-containing amino acids have been used as substitutes for sulfite to prevent browning, alone or in combination (Dudley \& Hotchkiss, 1989). Several studies have shown that Natureseal ${ }^{\circledR}$ (AS1: ascorbic acid and AS5: citric acid) products can reduce browning in fresh-cut fruit slices (Abbott et al., 2004; Rupasinghe et al., 2005; Toivonen, 2008).

The use of synthetic chemicals for controlling browning is becoming less acceptable to consumers (Lu and Toivonen, 2000). Therefore, efforts have been focused on use of natural materials (Sapers, 1993). Whey protein concentrate (WPC) edible coatings in combination with anti-browning 
agents effectively extended the shelf-life of minimally processed apple slices by two weeks when stored in packed trays at cold storage (Lee et al., 2003). Whey proteinbased coatings without incorporation of antioxidants were more effective in reducing enzymatic browning of 'Golden Delicious' apples than hydroxypropyl methylcellulose based coatings (Perez-Gago et al., 2005). Earlier study (Abubakr et al., 2012) showed that skim milk hydrolysate (SMH) from fermentation with the selected LAB has antioxidant activity, thus it may be possible that the peptide generated may also have antibrowning activity. Therefore, this study evaluated the antibrowning activity of SMH fermented by Lactobacillus plantarum 1 and Leuconstoc mesenteroides on fruits and potatoes slices. This would be useful to maintain the acceptable quality of minimally processed fruits and potatoes.

\section{Materials and Methods}

\section{Samples}

The samples used were apple, banana, Chinese pears and potatoes obtained from supermarket in Nilai. Each sample was washed by distilled water then cut by knife into slices and exposed to air at room temperature. Development of brown color on exposed side of the slices was monitored visually and the time taken for observable brown color formation was noted. Slices of Chinese pear and potatoes showed fast browning color formation than banana and apple, and thus Chinese pear and potatoes were selected for further study.

\section{Slices preparation and treatment condition}

The Chinese pears and potatoes were initially washed in water then peeled and cored. After that, each sample was cut into slices. The slices were dipped into ascorbic acid (AA), citric acid (CA), solutions of SMH-L. plantarum 1 (SMH1), SMH-Ln. mesenteroides (SMH2) and combing $\mathrm{SMH}-$ L. plantarum 1+ SMH-Ln. mesenteroides (SMH1+SMH2) at different concentration for all (1, 2, 3 and 4\% w/v) for 5 min (Rocha et al., 1998; Lu et al., 2007). Then all slices were placed in Petri dishes and exposed to air at room temperature for $0,3,6,12$ and $24 \mathrm{~min}$. Chinese pear and potato slices were dipped in distilled water served as control. The experiments were done in triplicate.

\section{Color assessment}

The changes in surface color of all the treated and control Chinese pear slices and potato slices and control (without treatment) were measured by a Hunter colorimeter (Minolta CR-300, Minolta Corp., Ramsey, $\mathrm{NJ})$ and measurements were made immediately after dipping the slices for 5 min as described above. The color was recorded using the CIE-L*, a*, $b^{*}$ scale, where $\mathrm{L}^{*}$ represents lightness, $\mathrm{a}^{*}$ represents chromaticity on a green $(-)$ to red $(+)$ axis and $b^{*}$ represents chromaticity on a blue $(-)$ to yellow $(+)$ axis. Numerical values of $a^{*}$ and $\mathrm{b}^{*}$ were converted into hue angle $\left(\right.$ Hue $=\tan ^{-1}\left(b^{*} / a^{*}\right)$ (Jeong et al., 2008).

\section{Browning index (BI)}

Twenty grams of all the treated Chinese pear slices, potato slices and control were homogenized in a laboratory blender for 2 min. Homogenates were centrifuged at $10000 \mathrm{rpm}$ for $15 \mathrm{~min}$ at $4{ }^{0} \mathrm{C}$, filtered through Whatman no. 2 filter paper (Whatman, Maidstone, Kent, UK) and the absorbance of clear juice was determined immediately at $420 \mathrm{~nm}$ and reported as the browning index (BI). Greater absorbance at $420 \mathrm{~nm}$ corresponds to greater browning (Jeong et al., 2008). 


\section{Estimation of total phenolic content (TPC)}

$1 \mathrm{~g}$ of all the treated Chinese pear slices, potato slices and control (without treatment) were extracted three times with $15 \mathrm{ml}$ of $50 \%$ methanol by maceration for $2 \mathrm{hr}$, then filtered and the final volume was made with $50 \%$ methanol up to $50 \mathrm{ml}$. Gallic acid was weighed $(10 \mathrm{mg})$ and dissolved in $100 \mathrm{ml}$ of $50 \%$ methanol. Lower concentrations of gallic acid (1, 2, 4, 6, 8 and $10 \mathrm{mg} / \mathrm{ml})$ were prepared by serially diluting stock solution (100 mg/ml). Samples and various concentrations of standard $(1 \mathrm{ml}$ each) were taken in test tubes, diluted with $10 \mathrm{ml}$ of distilled water, $1.5 \mathrm{ml}$ Folin Ciocalteu's reagent was added and was kept at room temperature for $5 \mathrm{~min}$ to which $4 \mathrm{ml}$ of $\mathrm{Na}_{2} \mathrm{CO}_{3}(20 \%$ w/v $)$ was added, the final volume adjusted to $25 \mathrm{ml}$ with distilled water, then agitated and allowed to stand for $30 \mathrm{~min}$ at room temperature. Absorbance was measured at $765 \mathrm{~nm}$ by a spectrophotometer (Varian Carry 50 Conc) for three parallel determinations. Quantification was done on the basis of a standard curve of gallic acid $(0-30 \mathrm{mg} / \mathrm{ml})$ (Appendix D Figure 1). Results were expressed as $\mathrm{mg}$ gallic acid equivalents (GAE) and percentage w/w (Hodzic et al., 2009).

\section{Statistical analysis}

The results were presented as mean \pm standard deviations of triplicate determinations and were statistically analyzed by two-way analysis of variance (ANOVA) using (Minitab, Inc.) version 15 (Germany), $\mathrm{p} \leq 0.05$ were considered statistically significant. Correlation analysis was conducted between color $\left(L^{*}, \mathrm{a}^{*}, \mathrm{~b}^{*}\right)$, total phenolic content (TPC) and browning index (BI). Attempts were made to establish the relationships between the parameters studied using " $\mathrm{R}$ " as the correlation factor.

\section{Results and Discussion}

Total phenolic content (tpc) and browning reaction

The TPC values varied with type of fruits and potato slices; Chinese pear slices contained higher levels of phenolic compounds with value $66.8 \mathrm{mg}$ GAEs/g than apple, potato and banana slices with values 50.3, 39.2 and $20.9 \mathrm{mg}$ GAEs/g, respectively. Browning of cut surfaces was observed within three minutes on Chinese pear slices compared to apple, potato and banana slices within 4, 4, and 6 minutes, respectively (Table 1 ). There was no significant difference $(p \geq 0.05)$ between the samples for browning reaction. Based on the shortest time taken for brown color to develop, Chinese pear was selected as type of fruits and potatoes as type of vegetables for future study.

\section{Color assessment and browning index (BI)}

The effect of antibrowning agents (AA, CA, SMH1, SMH2 and SMH1+SMH2) on Chinese pear and potato slices was investigated. Browning reaction was assessed by measuring degree of color (insoluble pigments $L^{*}, \mathrm{a}^{*}, \mathrm{~b}^{*}$ ) and browning index (soluble pigments $\mathrm{BI}$ ) of Chinese pear and potato slices before and after treated with antibrowning agents. The degree of color and BI of Chinese pear and potato slices treated with antibrowning agents was not affected ( $p \geq 0.05$ ) by the concentration of antibrowning agents used 1 to $4 \%(\mathrm{w} / \mathrm{v})$. All the antibrowning agents at concentration $1 \%$ were observed able to inhibit the browning reaction in both the Chinese pear and potato slices. The $L^{*}$ and $\mathrm{dE}^{*}$ values of Chinese pear and potato slices treated with all antibrowning agents were found to increase slightly and remained 
approximately constant thereafter within 24 min while $a^{*}$ and $b^{*}$ values decreased within $24 \mathrm{~min}$ compared to the control. The $L^{*}$ values of Chinese pear slices treated whit AA was $70.8 \%$, followed by $\mathrm{SMH} 1+\mathrm{SMH} 2, \mathrm{SMH} 1, \mathrm{CA}$ and $\mathrm{SMH} 2$ with values $70.1,69.7,67.0$ and $66.4 \%$, respectively after $24 \mathrm{~min}$. The $\mathrm{a}^{*}$ values of Chinese pear slices treated with $\mathrm{CA}$ was 0.14, followed by SMH1+SMH2, AA, SMH1and SMH2 with values $0.22,0.22$, 0.36 and 0.44 , respectively after $24 \mathrm{~min}$. The $b^{*}$ values of Chinese pear slices treated with CA was 16.5 , followed by AA, $\mathrm{SMH} 1+\mathrm{SMH} 2, \mathrm{SMH} 2$ and SMH1 with values 18.5, 18.7, 20.1 and 21.26, respectively at $24 \mathrm{~min}$. The $\mathrm{dE}^{*}$ values of Chinese pear slices treated with $\mathrm{CA}$ was 73.4, followed by AA, SMH1+SMH2, SMH1 and SMH2 with values 72.6, 71.3, 69.9 and 67.3 , respectively at $24 \mathrm{~min}$. The $\mathrm{BI}$ values of Chinese pear slices were lower when treated with $\mathrm{CA}, \mathrm{SMH} 1+\mathrm{SMH} 2, \mathrm{AA}$, SMH1 and SMH2 with values 0.26, 0.28, $0.29,0.30$ and 0.34 , respectively at $24 \mathrm{~min}$ (Tables 3, 4, 5, 6 and 7). In contrast, the control becomes darker $\left(L^{*}=46.2 \%\right.$, a* $=$ $5.85, \mathrm{~b}^{*}=23.7, \mathrm{dE}^{*}=46.1$ and $\mathrm{BI}=0.65$ ) (Table 2). Similar colour values were reported for potato slices when treated with all the antibrowning agents (Table 8, 9, 10, 11, 12 and 13) and no significant difference was observed between Chinese pear and potato slices treated with the five antibrowning agents evaluated. The results indicated that the Chinese pear and potato slices treated with $\mathrm{SMH} 1+\mathrm{SMH} 2$ was comparable to $\mathrm{AA}$ and $\mathrm{CA}$ for prevent browning reaction.

\section{Estimation of total phenolic content (TPC)}

TPC of Chinese pear and potato slices slightly decreased with increasing concentration of antibrowning agents and time of exposure to air at room temperature. There were no significant differences $(p \geq$ 0.05 ) between antibrowning agents and TPC of Chinese pear and potato slices treated within 24 min compared to the control. The TPC values of Chinese pear slices treated with AA was $59.5 \mathrm{mg}$ GAEs/g, $\mathrm{SMH} 1+\mathrm{SMH} 2, \mathrm{SMH} 1, \mathrm{CA}$ and SMH2 with values 59.7, 61.1, 62.5 and $63.0 \mathrm{mg}$ GAEs/g, respectively after $24 \mathrm{~min}$ (Table 14). In contrast, the TPC value of control was higher (80.2 $\mathrm{mg}$ GAEs/g) after $24 \mathrm{~min}$. Similarly, lower values of TPC were observed for potato slices treated with AA (30.9 mg GAEs/g), and SMH1+SMH2, CA, SMH2 and SMH1 with values 31.5, 32.3, 33.5 and $33.9 \mathrm{mg}$ GAEs/g, respectively after $24 \mathrm{~min}$. In contrast, the TPC value of control was increased within $24 \mathrm{~min}(48.2 \mathrm{mg}$ GAEs/g) Table 15. The results indicate that the slices of Chinese pear and potato treated with combining $\mathrm{SMH} 1+\mathrm{SMH} 2$ inhibited browning reaction comparable to $\mathrm{AA}$ as shown by reduction of TPC.

Relationship between color $\left(L^{*}, \mathrm{a}^{*}, \mathrm{~b}^{*}\right.$, dE*), total phenolic content (TPC) and browning index (BI)

Attempts were made to establish the relationships among the parameters studied for antibrowning agent treated Chinese pear and potato slices. A negative correlation between TPC and $L^{*}, \mathrm{dE}^{*}$ and BI but, a positive correlation between TPC and $\mathrm{a}^{*}, \mathrm{~b}^{*}$ for all treated samples was observed (Table 16 and Table 18). While, the results showed a positive correlation between BI and $L^{*}$, $\mathrm{dE}^{*}$ but, a negative correlation between $\mathrm{a}^{*}$ and $b^{*}$ for all treated samples was observed (Table 17 and Table 19). The color changes in Chinese pear and potato slices treated with AA, CA, SMH1, SMH2 and SMH1+ $\mathrm{SMH} 2$ determined by absorbance at $420 \mathrm{~nm}$ (soluble pigments) expressed as the BI and lightness (insoluble pigments) expressed as 
$L^{*}$ values were a negative correlated with the total phenolic content. TPC in Chinese pear and potato slices are closely related to the color changes that occur in Chinese pear and potato slices during long time.

An important issue in fresh-cut fruits and vegetables processing is the control of discoloration (pinking, reddening or blackening) or browning at cut surfaces. Oxidative browning is usually caused by the enzyme polyphenol oxidase (PPO) which, in the presence of $\mathrm{O}_{2}$ converts phenolic compounds in fruits and vegetables into dark colored pigments (Beaulieu and Baldwin, 2002). Various antibrowning agents as alternatives of sulfite have been were investigated. The $\mathrm{CA}$ and $\mathrm{AA}$ have been reported extensively for their antibrowning activity in minimally processed fruits and vegetables (Son et al., 2001; Lu et al., 2007). CA is a chelating agent and acidulates, reducing $\mathrm{pH}$ and chelating copper in the active site of polyphenol oxidase and, therefore, inactivating the enzyme polyphenol oxidase (Gurbuz \& Lee, 1997; Lee et al., 2003; Lu et al., 2007).

Many previous studies have proved that when the color became darker, producing a decrease in $L^{*}$ values and more yellow, producing an increase in $\mathrm{a}^{*}$ and $\mathrm{b}^{*}$ values in fruits and vegetables (Lee, 1999; Apintanapong et al., 2007; Lu et al., 2007). In this research, the effect of five antibrowning agents on Chines pear and potato slices browning was investigated using tristimulus colorimeter that can be applied directly to cut surfaces. The results showed good browning inhibitory activity through increase $L^{*}$ values and decrease $a^{*}$ and $b^{*}$ values with increasing the time of exposure to air at room temperature for all treatment compare with control (without treated). However, when the samples slices were treated with combining antibrowning agents SMH1+SMH2 showed inhibited browning reaction comparable to AA beater than used each one alone. No reports have been found regarding the effect of protein with antioxidant activity on the activity of browning in Chinese pear and potato slices. However, effects of AA and CA have been reported in other fresh cut fruits. Therefore, this study was first report using $\mathrm{SMH}$ protein as antibrowning agents (new natural source) to prevent or inhibit browning in fruits and vegetables. Suttirak and Supranee, (2010) reported that the use of mixtures of various antibrowning agents conducive to increased antibrowning efficiency is presumably due to the collaborative inhibitory mechanism of the constituents these results were similar to the results obtained from mixing of SMH1 and SMH2 beater than used each one speared to inhibit browning reaction in this study. The effects in color of apple slices have been observed previously with mixed antibrowning agents (Son et al., 2001). The effectiveness on browning prevention is mainly dependent on the produce types and cultivars, and concentrations of antibrowning agents. On the other hand, efficiency of respective AA, $\mathrm{CA}$ and $\mathrm{OA}$ on delaying browning can be enhanced by addition of an antibrowning agent possessing a different inhibitory mechanism and/or superior stability (Suttirak and Supranee, 2010).

Enzymatic browning is a significant problem in a number of fruits and vegetables such as strawberry (Chisari et al., 2007), grape (Munoz et al., 2004), potato (Lee and Park, 2007), and lettuce (GawlikDziki et al., 2007). The discoloration in fruits and vegetables by enzymatic browning, resulting from conversion of phenolic compounds to o-quinones which subsequently polymerize to be a brown or dark pigment. Thus it has been discovered that browning is mainly related to PPO activity, or to phenolic 
content. Our study demonstrated that the antibrowning agents affected the total phenolic content as compared to control. For all samples the TPC decreased with increasing concentration of antibrowning agents and longer exposure time. A decrease in degree of browning correlates with decrease in phenolic content. Jeong et al., (2008) reported that influenced the antibrowning agents treatments. Some authors who worked with apples and peaches noticed an increase in degree of browning with an increase in phenolic content and suggest that the degree of browning is determined by the amount of phenolic compounds present in the fruits (Coseteng and Lee, 1987; Lee et al., 1990).
Aminot et al., (1992) found that the degree of browning measured by absorbance at 420 $\mathrm{nm}$ (soluble pigments) and lightness $L$ (insoluble pigments) was closely related to amount of phenols degraded. Prohens et al. (2005) indicated that the selection for a reduced degree of browning in commercial varieties has resulted probably in the indirect selection of materials with lower concentrations of phenolic compounds.

The browning index (BI) of Chinese pear and potato slice measured by absorbance at $420 \mathrm{~nm}$ (soluble pigments) had small absorbance with increasing concentration of antibrowning agents and exposure time compared to control which had higher BI.

Table.1 Total phenolic content and time for observable browning color of fruits and potato slices

\begin{tabular}{ccc}
\hline Samples & TPC $(\mathbf{m g}$ GAEs/g) & Time $(\mathbf{m i n})$ \\
\hline Chinese pear & $66.8 \pm 0.089$ & $3 \pm 0.12$ \\
Apple & $50.3 \pm 0.322$ & $4 \pm 0.35$ \\
Banana & $20.9 \pm 0.268$ & $6 \pm 0.26$ \\
Potato & $39.2 \pm 0.322$ & $4 \pm 0.11$ \\
\hline
\end{tabular}

${ }^{\mathrm{a}}$ Results were mean values of triplicate determinations $\pm \mathrm{sd}$.

Table.2 Effect of distilled water on degree of color and browning index (BI) of Chinese pear slices as control.

\begin{tabular}{|c|c|c|c|c|c|}
\hline \multirow{2}{*}{ Time (min) } & \multicolumn{4}{|c|}{ Degree of color $^{\mathrm{a}}$} & \multirow{2}{*}{$\begin{array}{c}\text { Browning } \\
\text { index (BI) }\end{array}$} \\
\hline & $L^{*}$ & $\mathbf{a}^{*}$ & $\mathbf{b}^{*}$ & $\mathrm{dE}^{*}$ & \\
\hline 0 & $55.1 \pm 0.01$ & $2.42 \pm 0.07$ & $16.9 \pm 0.19$ & $60.2 \pm 0.01$ & $0.0 \pm 0.00$ \\
\hline 3 & $54.9 \pm 0.54$ & $3.15 \pm 0.05$ & $17.4 \pm 0.02$ & $52.8 \pm 0.23$ & $0.55 \pm 0.11$ \\
\hline 6 & $53.4 \pm 0.16$ & $3.70 \pm 0.76$ & $19.8 \pm 0.90$ & $50.1 \pm 0.12$ & $0.59 \pm 0.09$ \\
\hline 12 & $48.5 \pm 0.31$ & $4.32 \pm 0.12$ & $22.6 \pm 0.11$ & $47.6 \pm 0.09$ & $0.62 \pm 0.01$ \\
\hline 24 & $46.2 \pm 0.11$ & $5.85 \pm 0.01$ & $23.7 \pm 0.13$ & $46.1 \pm 0.45$ & $0.65 \pm 0.14$ \\
\hline
\end{tabular}


Table.3 Effect of AA (1\% w/v) on degree of color and browning index (BI) of Chinese pear slices

\begin{tabular}{lccccc}
\hline \multirow{2}{*}{ Time (min) } & \multicolumn{4}{c}{ Degree of color ${ }^{\mathbf{a}}$} & \multirow{2}{*}{$\begin{array}{c}\text { Browning } \\
\text { index (BI) }\end{array}$} \\
\cline { 2 - 5 } & $\boldsymbol{L}^{*}$ & $\mathbf{a}^{*}$ & $\mathbf{b}^{*}$ & $\mathbf{d E}^{*}$ & $0.0 \pm 0.00$ \\
0 & $64.9 \pm 0.14$ & $2.37 \pm 0.23$ & $22.6 \pm 0.61$ & $63.1 \pm 0.12$ & $0.14 \pm 0.05$ \\
3 & $66.4 \pm 0.12$ & $1.45 \pm 0.02$ & $19.6 \pm 0.41$ & $66.0 \pm 0.25$ & $0.34 \pm 0.05$ \\
6 & $68.0 \pm 0.74$ & $0.55 \pm 0.31$ & $19.5 \pm 0.12$ & $68.9 \pm 0.47$ & $0.31 \pm 0.13$ \\
12 & $69.5 \pm 0.19$ & $0.43 \pm 0.02$ & $19.0 \pm 0.16$ & $70.8 \pm 0.07$ & $0.30 \pm 0.24$ \\
24 & $70.8 \pm 0.02$ & $0.22 \pm 0.27$ & $18.5 \pm 0.04$ & $72.6 \pm 0.31$ & $0.29 \pm 0.02$ \\
\hline
\end{tabular}

${ }^{\mathrm{a}}$ is insoluble pigments; ${ }^{\mathrm{b}}$ is soluble pigments.

Table.4 Effect of CA (1 \% w/v) on degree of color and browning index (BI) of Chinese pear slices

\begin{tabular}{|c|c|c|c|c|c|}
\hline \multirow{2}{*}{ Time (min) } & \multicolumn{4}{|c|}{ Degree of color $^{\text {a }}$} & \multirow{2}{*}{$\begin{array}{l}\text { Browning } \\
\text { index }(\mathrm{BI})^{\mathrm{b}}\end{array}$} \\
\hline & $L^{*}$ & $\mathbf{a}^{*}$ & $\mathbf{b}^{*}$ & $\mathrm{dE}^{*}$ & \\
\hline 0 & $62.8 \pm 0.03$ & $2.09 \pm 0.20$ & $19.4 \pm 0.22$ & $64.5 \pm 0.11$ & $0.0 \pm 0.00$ \\
\hline 3 & $63.7 \pm 0.46$ & $1.59 \pm 0.15$ & $18.8 \pm 0.47$ & $67.0 \pm$ & 0.23 \\
\hline 6 & $65.9 \pm 0.80$ & $1.47 \pm 0.21$ & $17.5 \pm 0.01$ & $68.2 \pm 0.22$ & $0.29 \pm 0.15$ \\
\hline 12 & $66.4 \pm 0.37$ & $0.44 \pm 0.06$ & $16.6 \pm 0.32$ & $71.4 \pm 0.05$ & $0.28 \pm 0.07$ \\
\hline 24 & $67.0 \pm 0.15$ & $0.14 \pm 0.29$ & $16.5 \pm 0.65$ & $73.4 \pm 0.33$ & $0.26 \pm 0.21$ \\
\hline
\end{tabular}

${ }^{\mathrm{a}}$ is insoluble pigments; ${ }^{\mathrm{b}}$ is soluble pigments.

Table.5 Effect of SMH1 (1 \% w/v) on degree of color and browning index (BI) of Chinese pear slices

\begin{tabular}{|c|c|c|c|c|c|}
\hline \multirow{2}{*}{ Time (min) } & \multicolumn{4}{|c|}{ Degree of color $^{\mathbf{a}}$} & \multirow{2}{*}{$\begin{array}{l}\text { Browning } \\
\text { index (BI) }\end{array}$} \\
\hline & $L^{*}$ & $a^{*}$ & $\mathbf{b}^{*}$ & $\mathrm{dE}^{*}$ & \\
\hline 0 & $63.1 \pm 0.21$ & $2.40 \pm 0.35$ & $24.1 \pm 0.26$ & $60.9 \pm 0.03$ & $0.0 \pm 0.00$ \\
\hline 3 & $64.3 \pm 0.27$ & $1.90 \pm 0.13$ & $22.9 \pm 0.15$ & $63.1 \pm 0.47$ & $0.36 \pm 0.21$ \\
\hline 6 & $66.5 \pm 0.04$ & $0.85 \pm 0.03$ & $22.4 \pm 0.78$ & $64.8 \pm 0.09$ & $0.34 \pm 0.06$ \\
\hline 12 & $68.1 \pm 0.65$ & $0.61 \pm 0.19$ & $22.1 \pm 0.03$ & $67.7 \pm 0.12$ & $0.33 \pm 0.13$ \\
\hline 24 & $69.7 \pm 0.19$ & $0.36 \pm 0.85$ & $21.2 \pm 0.36$ & $69.9 \pm 0.26$ & $0.30 \pm 0.03$ \\
\hline
\end{tabular}

${ }^{\mathrm{a}}$ is insoluble pigments; ${ }^{\mathrm{b}}$ is soluble pigments.

Table.6 Effect of SMH2 (1 \% w/v) on degree of color and browning index (BI) of Chinese pear slices

\begin{tabular}{lccccc}
\hline \multirow{2}{*}{ Time (min) } & \multicolumn{4}{c}{ Degree of color } & Browning \\
\cline { 2 - 5 } & $\boldsymbol{L}^{*}$ & $\mathbf{a}^{*}$ & $\mathbf{b}^{*}$ & $\mathbf{d E}^{*}$ & Bndex (BI) $^{\mathbf{b}}$ \\
\hline 0 & $61.7 \pm 0.14$ & $2.38 \pm 0.35$ & $25.6 \pm 0.26$ & $59.8 \pm 0.21$ & $0.0 \pm 0.00$ \\
3 & $62.9 \pm 0.12$ & $1.99 \pm 0.13$ & $23.7 \pm 0.15$ & $60.4 \pm 0.14$ & $0.38 \pm 0.06$ \\
6 & $63.7 \pm 0.78$ & $1.00 \pm 0.03$ & $22.9 \pm 0.78$ & $62.5 \pm 0.12$ & $0.37 \pm 0.01$ \\
12 & $64.3 \pm 0.03$ & $0.75 \pm 0.19$ & $21.3 \pm 0.03$ & $65.1 \pm 0.06$ & $0.35 \pm 0.28$ \\
24 & $66.4 \pm 0.37$ & $0.44 \pm 0.85$ & $20.1 \pm 0.36$ & $67.3 \pm 0.42$ & $0.34 \pm 0.13$ \\
\hline
\end{tabular}

${ }^{\mathrm{a}}$ is insoluble pigments; ${ }^{\mathrm{b}}$ is soluble pigments. 
Table.7 Effect of SMH1+SMH2 (1\% w/v) on degree of color and browning index (BI) of Chinese pear slices

\begin{tabular}{lccccc}
\hline \multirow{2}{*}{ Time (min) } & \multicolumn{4}{c}{ Degree of color a } & Browning \\
\cline { 2 - 5 } & $\boldsymbol{L}^{*}$ & $\mathbf{a}^{*}$ & $\mathbf{b}^{*}$ & $\mathbf{d E}^{*}$ & index (BI)b \\
\hline 0 & $63.5 \pm 0.14$ & $2.39 \pm 0.23$ & $22.1 \pm 0.61$ & $62.2 \pm 0.12$ & $0.0 \pm 0.00$ \\
3 & $65.1 \pm 0.12$ & $1.76 \pm 0.02$ & $20.3 \pm 0.41$ & $65.1 \pm 0.02$ & $0.33 \pm 0.14$ \\
6 & $66.5 \pm 0.74$ & $0.73 \pm 0.31$ & $19.7 \pm 0.12$ & $66.8 \pm 0.15$ & $0.31 \pm 0.31$ \\
12 & $68.2 \pm 0.19$ & $0.57 \pm 0.02$ & $19.0 \pm 0.16$ & $68.7 \pm 0.82$ & $0.30 \pm 0.06$ \\
24 & $70.1 \pm 0.02$ & $0.22 \pm 0.27$ & $18.7 \pm 0.04$ & $71.3 \pm 0.18$ & $0.28 \pm 0.12$ \\
\hline
\end{tabular}

${ }^{\mathrm{a}}$ is insoluble pigments; ${ }^{\mathrm{b}}$ is soluble pigments.

Table.8 Effect of distilled water on degree of color and browning index (BI) of potato slices as control

\begin{tabular}{|c|c|c|c|c|c|}
\hline \multirow{2}{*}{ Time (min) } & \multicolumn{4}{|c|}{ Degree of color $^{\mathrm{a}}$} & \multirow{2}{*}{$\begin{array}{l}\text { Browning } \\
\text { index }(B I)^{b}\end{array}$} \\
\hline & $L^{*}$ & $\mathbf{a}^{*}$ & $\mathbf{b}^{*}$ & $\mathrm{dE}^{*}$ & \\
\hline 0 & $60.7 \pm 0.17$ & $3.90 \pm 0.07$ & $20.1 \pm 0.06$ & $63.8 \pm 0.23$ & $0.0 \pm 0.00$ \\
\hline 3 & $59.9 \pm 0.28$ & $3.98 \pm 0.05$ & $21.5 \pm 0.26$ & $62.3 \pm 0.23$ & $0.20 \pm 0.02$ \\
\hline 6 & $57.0 \pm 0.11$ & $4.12 \pm 0.76$ & $22.0 \pm 0.17$ & $60.7 \pm 0.35$ & $0.21 \pm 0.02$ \\
\hline 12 & $56.4 \pm 0.09$ & $4.67 \pm 0.12$ & $22.9 \pm 0.03$ & $58.0 \pm 0.17$ & $0.24 \pm 0.03$ \\
\hline 24 & $54.9 \pm 0.76$ & $5.94 \pm 0.01$ & $24.8 \pm 0.28$ & $55.4 \pm 0.51$ & $0.28 \pm 0.05$ \\
\hline
\end{tabular}

${ }^{\mathrm{a}}$ is insoluble pigments; ${ }^{\mathrm{b}}$ is soluble pigments.

Table.9 Effect of AA (1\% w/v) on degree of color and browning index (BI) of potato slices

\begin{tabular}{|c|c|c|c|c|c|}
\hline \multirow{2}{*}{ Time (min) } & \multicolumn{4}{|c|}{ Degree of color $^{\text {a }}$} & \multirow{2}{*}{$\begin{array}{l}\text { Browning } \\
\text { index }(\mathrm{BI})^{b}\end{array}$} \\
\hline & $L^{*}$ & $\mathbf{a}^{*}$ & $\mathbf{b}^{*}$ & $\mathrm{dE}^{*}$ & \\
\hline 0 & $66.2 \pm 0.03$ & $3.24 \pm 0.23$ & $24.1 \pm 0.14$ & $65.4 \pm 0.02$ & $0.0 \pm 0.00$ \\
\hline 3 & $67.6 \pm 0.67$ & $2.09 \pm 0.02$ & $21.3 \pm 0.81$ & $67.3 \pm 0.04$ & $0.15 \pm 0.02$ \\
\hline 6 & $68.0 \pm 0.42$ & $1.32 \pm 0.31$ & $20.2 \pm 0.01$ & $69.9 \pm 0.05$ & $0.15 \pm 0.01$ \\
\hline 12 & $69.7 \pm 0.16$ & $0.87 \pm 0.02$ & $19.6 \pm 0.11$ & $70.9 \pm 0.03$ & $0.13 \pm 0.01$ \\
\hline 24 & $71.4 \pm 0.13$ & $0.52 \pm 0.27$ & $19.0 \pm 0.46$ & $72.9 \pm 0.03$ & $0.13 \pm 0.01$ \\
\hline
\end{tabular}

${ }^{\mathrm{a}}$ is insoluble pigments; ${ }^{\mathrm{b}}$ is soluble pigments.

Table.10 Effect of CA (1\% w/v) on degree of color and browning index (BI) of potato slices

\begin{tabular}{lccccc}
\hline \multirow{2}{*}{ Time (min) } & \multicolumn{4}{c}{ Degree of color } & Browning \\
\cline { 2 - 5 } & $\boldsymbol{L}^{*}$ & $\mathbf{a}^{*}$ & $\mathbf{b}^{*}$ & dE $^{*}$ & index $(\mathbf{B I})^{\mathbf{b}}$ \\
\hline 0 & $64.1 \pm 0.13$ & $2.32 \pm 0.20$ & $19.8 \pm 0.07$ & $68.7 \pm 0.03$ & $0.0 \pm 0.00$ \\
3 & $65.9 \pm 0.93$ & $1.78 \pm 0.15$ & $17.7 \pm 0.11$ & $70.3 \pm 0.17$ & $0.15 \pm 0.01$ \\
6 & $66.5 \pm 0.06$ & $1.65 \pm 0.21$ & $17.2 \pm 0.82$ & $70.7 \pm 0.24$ & $0.14 \pm 0.02$ \\
12 & $67.1 \pm 0.29$ & $0.95 \pm 0.06$ & $16.9 \pm 0.46$ & $72.3 \pm 0.15$ & $0.13 \pm 0.01$ \\
24 & $67.8 \pm 0.10$ & $0.27 \pm 0.29$ & $16.0 \pm 0.13$ & $73.8 \pm 0.10$ & $0.12 \pm 0.00$ \\
\hline
\end{tabular}

${ }^{\mathrm{a}}$ is insoluble pigments; ${ }^{\mathrm{b}}$ is soluble pigments. 
Table.11 Effect of SMH1 (1 \% w/v) on degree of color and browning index (BI) of potato slices

\begin{tabular}{lccccc}
\hline \multirow{2}{*}{ Time (min) } & \multicolumn{4}{c}{ Degree of color ${ }^{\mathbf{a}}$} & \multirow{2}{*}{$\begin{array}{c}\text { Browning } \\
\text { index (BI) }\end{array}$} \\
\cline { 2 - 6 } & $\boldsymbol{L}^{*}$ & $\mathbf{a}^{*}$ & $\mathbf{b}^{*}$ & $\mathbf{d E}^{*}$ & \\
\hline 0 & $61.4 \pm 0.12$ & $3.30 \pm 0.12$ & $26.3 \pm 0.14$ & $68.4 \pm 0.18$ & $0.0 \pm 0.00$ \\
3 & $62.1 \pm 0.81$ & $2.27 \pm 0.45$ & $24.2 \pm 0.81$ & $69.1 \pm 0.96$ & $0.17 \pm 0.06$ \\
6 & $65.3 \pm 0.40$ & $1.54 \pm 0.09$ & $21.9 \pm 0.01$ & $69.8 \pm 0.29$ & $0.15 \pm 0.03$ \\
12 & $66.7 \pm 0.42$ & $1.16 \pm 0.26$ & $20.3 \pm 0.11$ & $70.5 \pm 0.27$ & $0.13 \pm 0.07$ \\
24 & $69.1 \pm 0.17$ & $0.97 \pm 0.33$ & $19.7 \pm 0.46$ & $71.0 \pm 0.50$ & $0.12 \pm 0.04$ \\
\hline
\end{tabular}

${ }^{\mathrm{a}}$ is insoluble pigments; ${ }^{\mathrm{b}}$ is soluble pigments.

Table.12 Effect of SMH2 (1 \% w/v) on degree of color and browning index (BI) of potato slices

\begin{tabular}{|c|c|c|c|c|c|}
\hline \multirow{2}{*}{ Time (min) } & \multicolumn{4}{|c|}{ Degree of color $^{a}$} & \multirow{2}{*}{$\begin{array}{l}\text { Browning } \\
\text { index }(B I)^{b}\end{array}$} \\
\hline & $L^{*}$ & $\mathbf{a}^{*}$ & $\mathbf{b}^{*}$ & $\mathrm{dE}^{*}$ & \\
\hline 0 & $60.1 \pm 0.22$ & $3.43 \pm 0.23$ & $26.7 \pm 0.54$ & $66.8 \pm 0.10$ & $0.0 \pm 0.00$ \\
\hline 3 & $60.9 \pm 0.19$ & $2.76 \pm 0.62$ & $25.5 \pm 0.11$ & $67.7 \pm 0.22$ & $0.19 \pm 0.01$ \\
\hline 6 & $62.8 \pm 0.18$ & $1.64 \pm 0.13$ & $23.9 \pm 0.04$ & $68.3 \pm 0.33$ & $0.17 \pm 0.04$ \\
\hline 12 & $65.1 \pm 0.06$ & $1.20 \pm 0.07$ & $21.5 \pm 0.44$ & $69.3 \pm 0.27$ & $0.16 \pm 0.02$ \\
\hline 24 & $67.9 \pm 0.76$ & $1.13 \pm 0.14$ & $20.1 \pm 0.17$ & $70.0 \pm 0.63$ & $0.13 \pm 0.01$ \\
\hline
\end{tabular}

${ }^{\mathrm{a}}$ is insoluble pigments; ${ }^{\mathrm{b}}$ is soluble pigments.

Table.13 Effect of SMH1+SMH2 (1\% w/v) on degree of color and browning index $(\mathrm{BI})$ of potato slices

\begin{tabular}{lccccc}
\hline \multirow{2}{*}{ Time (min) } & \multicolumn{4}{c}{ Degree of color ${ }^{\mathbf{a}}$} & \multicolumn{1}{c}{$\begin{array}{c}\text { Browning } \\
\text { index (BI) }\end{array}$} \\
\cline { 2 - 5 } & $\boldsymbol{L}^{*}$ & $\mathbf{a}^{*}$ & $\mathbf{b}^{*}$ & $\mathbf{d E}^{*}$ & $0.0 \pm 0.00$ \\
0 & $64.5 \pm 0.24$ & $2.39 \pm 0.20$ & $20.0 \pm 0.13$ & $65.3 \pm 0.03$ & $0.00 .16 \pm 0.02$ \\
3 & $64.9 \pm 0.87$ & $1.87 \pm 0.15$ & $18.1 \pm 0.12$ & $66.8 \pm 0.66$ & $0.16 \pm 0.01$ \\
6 & $65.7 \pm 0.12$ & $1.72 \pm 0.21$ & $17.8 \pm 0.76$ & $69.5 \pm 0.02$ & $0.15 \pm 0.01$ \\
12 & $66.5 \pm 0.34$ & $1.10 \pm 0.06$ & $17.1 \pm 0.03$ & $70.6 \pm 0.32$ & $0.13 \pm 0.03$ \\
24 & $69.1 \pm 0.06$ & $0.68 \pm 0.29$ & $16.4 \pm 0.35$ & $71.2 \pm 0.26$ & $0.12 \pm 0.02$ \\
\hline
\end{tabular}

${ }^{\mathrm{a}}$ is insoluble pigments; ${ }^{\mathrm{b}}$ is soluble pigments.

Table.14 Effect of antibrowning agents (1\% w/v) on total phenols content (mg GAEs/g) of Chinese pear slices

\begin{tabular}{|c|c|c|c|c|c|c|}
\hline \multirow{2}{*}{$\begin{array}{l}\text { Time } \\
(\text { min) }\end{array}$} & \multirow{2}{*}{ Control $^{\mathrm{a}}$} & \multicolumn{5}{|c|}{ Antibrowning agents } \\
\hline & & $\mathrm{AA}^{\mathrm{b}}$ & $\mathrm{CA}^{\mathrm{c}}$ & $\mathrm{SMH}^{\mathrm{d}}$ & $\mathrm{SMH} 2^{\mathrm{e}}$ & $\mathrm{SMH} 1+\mathrm{SMH} 2^{\mathrm{f}}$ \\
\hline 0 & $66.8 \pm 0.26$ & $65.5 \pm 0.32$ & $65.3 \pm 0.23$ & $66.1 \pm 0.12$ & $66.5 \pm 0.09$ & $64.1 \pm 0.32$ \\
\hline 3 & $72.5 \pm 0.23$ & $64.2 \pm 0.17$ & $64.3 \pm 0.15$ & $65.9 \pm 0.71$ & $66.0 \pm 0.23$ & $62.9 \pm 0.26$ \\
\hline 6 & $75.6 \pm 0.23$ & $63.5 \pm 0.35$ & $63.4 \pm 0.44$ & $63.9 \pm 0.09$ & $64.6 \pm 0.43$ & $61.3 \pm 0.40$ \\
\hline 12 & $76.1 \pm 0.08$ & $62.9 \pm 0.26$ & $62.5 \pm 0.32$ & $63.0 \pm 0.76$ & $63.9 \pm 0.13$ & $60.0 \pm 0.32$ \\
\hline 24 & $80.2 \pm 0.08$ & $59.5 \pm 0.32$ & $62.5 \pm 0.93$ & $61.1 \pm 0.19$ & $63.0 \pm 0.14$ & $59.7 \pm 0.32$ \\
\hline
\end{tabular}


Table.15 Effect of antibrowning agents $(1 \% \mathrm{w} / \mathrm{v})$ on total phenols content (mg GAEs/g) of potato slices

\begin{tabular}{|c|c|c|c|c|c|c|}
\hline \multirow{2}{*}{$\begin{array}{l}\text { Time } \\
\text { (min) }\end{array}$} & \multirow{2}{*}{ Control $^{\mathrm{a}}$} & \multicolumn{5}{|c|}{ Antibrowning agents } \\
\hline & & $\mathrm{AA}^{\mathrm{b}}$ & $\mathrm{CA}^{\mathrm{c}}$ & $\mathrm{SMH}^{\mathrm{d}}$ & $\mathrm{SMH} 2^{\mathrm{e}}$ & $\mathrm{SMH} 1+\mathrm{SMH} 2^{\mathrm{f}}$ \\
\hline 0 & $39.2 \pm 0.06$ & $38.1 \pm 0.32$ & $37.9 \pm 0.12$ & $38.6 \pm 0.02$ & $38.9 \pm 0.32$ & $37.5 \pm 0.23$ \\
\hline 3 & $41.1 \pm 0.12$ & $36.7 \pm 0.09$ & $35.4 \pm 0.21$ & $37.1 \pm 0.65$ & $38.2 \pm 0.21$ & $36.1 \pm 0.40$ \\
\hline 6 & $43.8 \pm 0.31$ & $35.0 \pm 0.11$ & $34.1 \pm 0.67$ & $35.6 \pm 0.31$ & $36.7 \pm 0.07$ & $35.3 \pm 0.09$ \\
\hline 12 & $45.6 \pm 0.21$ & $33.6 \pm 0.20$ & $32.7 \pm 0.14$ & $34.7 \pm 0.25$ & $35.1 \pm 0.39$ & $33.5 \pm 0.22$ \\
\hline 24 & $48.2 \pm 0.43$ & $30.9 \pm 0.32$ & $32.3 \pm 0.32$ & $33.9 \pm 0.32$ & $33.5 \pm 0.71$ & $31.5 \pm 0.19$ \\
\hline
\end{tabular}

${ }^{\mathrm{a}}$ Potato slices without antibrowning agents.

${ }^{\mathrm{b}}$ AA: Ascorbic acid

${ }^{\mathrm{c}} \mathrm{CA}$ : Citric acid

${ }^{\mathrm{d}} \mathrm{SMH} 1:$ SMH- L. plantarum 1

${ }^{\mathrm{e}} \mathrm{SMH} 2: \mathrm{SMH}-$ Ln. mesenteroides,

${ }^{\mathrm{f}} \mathrm{SMH} 1+\mathrm{SMH} 2: \mathrm{SMH}-$ L. plantarum 1+ SMH- Ln. mesenteroides.

Table.16 Correlations (R2) between total phenolic content (TPC mg GAEs/g) and several parameters of Chinese pear slices before and after treated by antibrowning agents a.

\begin{tabular}{|c|c|c|c|c|c|c|}
\hline $\begin{array}{c}\text { Quality } \\
\text { parameters }\end{array}$ & Control $^{b}$ & $\mathbf{A} \mathbf{A}^{\mathbf{c}}$ & $\mathrm{CA}^{\mathbf{d}}$ & $\mathbf{S M H 1}^{\mathrm{e}}$ & $\mathrm{SMH}^{\mathrm{f}}$ & $\begin{array}{l}\text { SMH1+ } \\
\text { SMH2 }^{\text {g }}\end{array}$ \\
\hline$L^{*}$ & -0.84 & -0.97 & -0.95 & -0.98 & -0.96 & -0.98 \\
\hline$a^{*}$ & 0.94 & 0.88 & 0.95 & 0.98 & 0.99 & 0.98 \\
\hline$b^{*}$ & 0.90 & 0.85 & 0.97 & 0.91 & 0.97 & 0.96 \\
\hline $\mathrm{dE}^{*}$ & -0.98 & -0.95 & -0.99 & -0.96 & -0.98 & -0.98 \\
\hline BI & 0.90 & -0.59 & -0.56 & -0.52 & -0.58 & -0.64 \\
\hline $\begin{array}{l}{ }^{\mathrm{a}} \text { Correlation is } \\
{ }^{\mathrm{b}} \text { Chinese pear } \\
{ }^{\mathrm{c}} \text { Ascorbic acid } \\
{ }^{\mathrm{e}} \mathrm{SMH} 1 \text { is } \mathrm{SMH} \\
{ }^{\mathrm{f}} \mathrm{SMH} 2 \text { is } \mathrm{SMH} \\
{ }^{\mathrm{g}} \mathrm{SMH} 1+\mathrm{SMH}\end{array}$ & $\begin{array}{l}\text { Snificant at } \mathrm{t} \\
\text { d potato slic } \\
\text { Citric acid. } \\
\text { L. plantarum } \\
\text { Ln. mesenter } \\
\text { SMH-L. pl }\end{array}$ & $\begin{array}{l}0.05 \text { le } \\
\text { withou }\end{array}$ & prow1 & ents. & & \\
\hline
\end{tabular}


Table.17 Correlations (R2) between browning index (BI) and several parameters of Chinese pear slices before and after treated by antibrowning agents a.

\begin{tabular}{lcccccc}
\hline $\begin{array}{c}\text { Quality } \\
\text { parameters }\end{array}$ & Control $^{\mathbf{b}}$ & $\mathbf{A A}^{\mathbf{c}}$ & $\mathbf{C A}^{\mathbf{d}}$ & $\mathbf{S M H 1}^{\mathbf{e}}$ & SMH2 $^{\mathbf{f}}$ & $\begin{array}{c}\text { SMH1+ } \\
\text { SMH2 }^{\mathbf{g}}\end{array}$ \\
\hline$L^{*}$ & -0.59 & 0.62 & 0.60 & 0.57 & 0.60 & 0.59 \\
$\mathrm{a}^{*}$ & 0.50 & -0.77 & -0.52 & -0.66 & -0.65 & -0.69 \\
$\mathrm{~b}^{*}$ & 0.69 & -0.92 & -0.58 & -0.73 & -0.69 & -0.82 \\
$\mathrm{dE}^{*}$ & -0.80 & 0.67 & 0.57 & 0.58 & 0.48 & 0.65 \\
\hline
\end{tabular}

${ }^{\mathrm{a}}$ Correlation is significant at the 0.05 level.

${ }^{\mathrm{b}}$ Chinese pear and potato slices without antibrowning agents.

${ }^{\mathrm{c}}$ Ascorbic acid, ${ }^{\mathrm{d}}$ Citric acid.

${ }^{\mathrm{e}} \mathrm{SMH} 1$ is SMH- L. plantarum 1.

${ }^{\mathrm{f}} \mathrm{SMH} 2$ is SMH- Ln. mesenteroides.

${ }^{\mathrm{g}} \mathrm{SMH} 1+\mathrm{SMH} 2$ is SMH- L. plantarum $1+\mathrm{SMH}-$ Ln. mesenteroides.

Table.18 Correlations (R2) between total phenolic content (TPC mg GAEs/g) and several parameters of potato slices before and after treated by antibrowning agents a.

\begin{tabular}{lcccccc}
\hline $\begin{array}{c}\text { Quality } \\
\text { parameters }\end{array}$ & Control $^{\mathbf{b}}$ & $\mathbf{A A}^{\mathbf{c}}$ & $\mathbf{C A}^{\mathbf{d}}$ & SMH1 $^{\mathbf{e}}$ & SMH2 $^{\mathbf{f}}$ & $\begin{array}{c}\text { SMH1+ } \\
\text { SMH2 }^{\mathbf{g}}\end{array}$ \\
\hline$L^{*}$ & -0.99 & -0.97 & -0.99 & -0.98 & -0.99 & -0.98 \\
$\mathrm{a}^{*}$ & 0.90 & 0.98 & 0.97 & 0.97 & 0.95 & 0.99 \\
$\mathrm{~b}^{*}$ & 0.98 & 0.94 & 0.97 & 0.99 & 0.99 & 0.94 \\
$\mathrm{dE}^{*}$ & -0.99 & -0.97 & -0.96 & -0.99 & -0.99 & -0.96 \\
$\mathrm{BI}^{\mathrm{N}}$ & 0.56 & -0.60 & -0.65 & -0.53 & -0.82 & -0.45 \\
\hline
\end{tabular}

${ }^{\mathrm{a}}$ Correlation is significant at the 0.05 level.

${ }^{\mathrm{b}}$ Chinese pear and potato slices without antibrowning agents.

${ }^{\mathrm{c}}$ Ascorbic acid, ${ }^{\mathrm{d}}$ Citric acid.

${ }^{\mathrm{e}} \mathrm{SMH} 1$ is SMH- L. plantarum 1.

${ }^{\mathrm{f}} \mathrm{SMH} 2$ is SMH- Ln. mesenteroides.

${ }^{\mathrm{g}} \mathrm{SMH} 1+\mathrm{SMH} 2$ is $\mathrm{SMH}-$ L. plantarum $1+\mathrm{SMH}-$ Ln. mesenteroides. 
Table.19 Correlations (R2) between browning index (BI) and several parameters of potato slices before and after treated by antibrowning agents a.

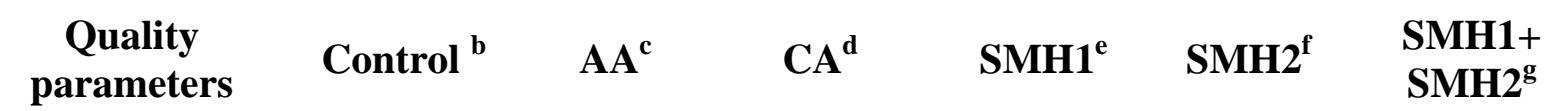

\begin{tabular}{lcccccc}
\hline$L^{*}$ & -0.83 & 0.55 & 0.76 & 0.78 & 0.98 & 0.44 \\
$\mathrm{a}^{*}$ & 0.65 & -0.76 & -0.51 & -0.67 & -0.88 & -0.50 \\
$\mathrm{~b}^{*}$ & 0.87 & -0.84 & -0.81 & -0.56 & -0.82 & -0.73 \\
$\mathrm{dE}^{*}$ & -0.82 & 0.70 & 0.63 & 0.53 & 0.87 & 0.59 \\
& & & & & &
\end{tabular}

${ }^{a}$ Correlation is significant at the 0.05 level.

${ }^{\mathrm{b}}$ Chinese pear and potato slices without antibrowning agents.

${ }^{\mathrm{c}}$ Ascorbic acid, ${ }^{\mathrm{d}}$ Citric acid.

${ }^{\mathrm{e}} \mathrm{SMH} 1$ is SMH- L. plantarum 1.

${ }^{\mathrm{f}} \mathrm{SMH} 2$ is SMH- Ln. mesenteroides.

${ }^{\mathrm{g}} \mathrm{SMH} 1+\mathrm{SMH} 2$ is $\mathrm{SMH}-$ L. plantarum $1+\mathrm{SMH}-$ Ln. mesenteroides.

Same results were reported by Wrolstad, (1976), the lowest BI corresponds to the least browning of the apple tissues. Our study indicates that both negative and positive relationships among the parameters studied for antibrowning agent treated Chinese pear and potato slices; a negative correlation was observed between TPC and $L^{*}$, Hue $\mathrm{dE}^{*}$ and BI also between BI and $\mathrm{a}^{*}$, $\mathrm{b}^{*}$ while a positive correlation was observed between TPC and $a^{*}, b^{*}$ also between BI and $L^{*}$ for both samples treated with SMH1, SMH2 and commonly used antibrowning agents. Similarity, Dykes et al., (2005) reported that the negative correlation between the $L^{*}$ value and total phenols ($0.69, \mathrm{p}<0.01)$. Also Jeong et al., 2008 demonstrated that the positive correlations $\left(\mathrm{R}^{2}<0.56\right)$ were found when total phenolic were plotted against $a^{*}$ and $b^{*}$. This further confirms that the browning reaction is related with total phenol content. The mechanism for enzymatic browning involves the interaction of phenolic compounds with PPO in the presence of oxygen (Kavrayan and Aydemir, 2001; Suttirak and Supranee, 2010).

Oxidative damage in fruits and vegetables during handling, processing and Storage, due to enzymatic oxidation of endogenous phenolic compounds catalysed PPO inherent in biological tissues (Nicolas et al., 1994) which leads to browning of tissue. The brown pigment formed in food and food stuffs, looks unpleasant appearance that generally associated with loss of nutritional and market values (Chen et al., 1991; Loganathan et al., 2011). The prevention of PPO-catalysed browning in food was usually accomplished by the addition of synthetic antioxidant compounds like ascorbic acid, citric acid, benzoic acid, cysteine and glutathione were an antioxidant 
compounds. Hence, there was an increase in need for substituting synthetic compounds with natural substances as food ingredients, and these types of studies could be an important topic from the standpoint of food science and technology (Murata et al., 1995; Loganathan et al., 2011). Therefore, the compounds inherent in natural origins are widely accepted by consumers in the market. Based on this notion, there have been a lot of reports on the PPO inhibitors occurring in natural resources using synthetic antioxidant compounds. However, no reports have been found on the scavenging effect of free radicals from the $\mathrm{SMH}$ that could prevent the oxidative damage that increase the shelf life of food stuffs. Loganathan et al., (2011) observed that the Agaricus heterocystis hot water soluble contained certain antioxidant substance or compounds which inhibited the oxidation of endogenous compounds present in the apple. We suggested that the SMH are believed to be a free radical scavenger and to prevent browning owing to its reducing power and chelating copper in the active site of polyphenol oxidase. Utilization of this SMH will be promised as a natural food additive for the prevention of color browning caused by PPO.

In conclusion, it can be concluded that SMH1 and SMH2 have both antibrowning activity comparable to AA and CA. Additionally, the LAB strains used in this study were able to generate bioactive peptides which have the antioxidant and antibrowning activities, a dual function of bioactive peptides that would be useful in the formulation of functional foods.

\section{References}

Abbott, J.A., Saftner, R.A., Kenneth, G.C., Vinyard, B.T., Janick, J. 2004. Consumer evaluation and quality measurement of fresh-cut slices of 'Fuji', 'Golden Delicious', 'GoldRush', and 'Granny Smith' apples. Postharvest Biol. Technol., 33: 127-140.

Abubakr, M., Zaiton, H., Mohamed, I., \& Sharifah, A. 2012. Antioxidant activity of lactic acid bacteria (LAB) fermented skim milk as determined by 1,1-diphenyl-2-picrylhydrazyl (DPPH) and ferrous chelating activity (FCA). African J. Microbiol. Res., 6: 63586364.

Amoit, M.J., Aubert, S., Nicolas, J., Goupy, P., Aparicio, P. 1992. Phenolic composition and browning susceptibility of various apple and pear cultivars at maturity. Bull. Liaison Groupe Polyphenols, 16: 4852.

Apintanapong, M., Cheachumluang, K., Suansawan, P., \& Thongprasert, N. 2007. Effect of antibrowning agents on banana slices and vacuum-fried slices. J. Food Agri. Environ., 5: 151157.

Beaulieu, J.C., Baldwin, E.A. 2002. Flavor and Aroma of Fresh-cut Fruits and Vegetables. In: Lamikanra O. (ed) Fresh-Cut Fruits and Vegetables. Science, Technology and Market. Boca Raton, FL, CRC Press, 391-425.

Buckley, M., Cowan, C., Mccarthy, M. 2007. The convenience food market in Great Britain: Convenience food lifestyle (CFL) segments. Appetite, 49: 600-617.

Burda, S., Oleszek, W., Lee, C.Y. 1990. Phenolic compounds and their changes in apples during maturation and cold storage. J. Sci. Food Agri., 38: 945948.

Chen, J.S., Wei, C., Rolle, R.S., Otwell, W.S., Balaban, M.O., Marshall, M.R. 1991. Inhibitory effect of kojic acid on some plant and crustacean polyphenol 
oxidase. J. Agri. Food Chem., 39: 1396-1401.

Chisari, M., Barbagallo, R.N., Spagna, G. 2007. Characterization of polyphenol oxidase and peroxidase and influence on browning of cold stored strawberry. J. Agri. Food Chem., 55: 3469- 3479.

Coseteng, M.Y., Lee, C.Y. 1987. Changes in apple polyphenoloxidase and polyphenol concentrations in relation to degree of browning. J. Food Sci., 52: 985- 989 .

Dudley, E.D., Hotchkiss, J.H. 1989. Cysteine as an inhibitor of polyphenoloxidase. J. Food Biochem., 13: $65-75$.

Dykes, L., Rooney, L.W., Waniska, R.D., Rooney, W.L. 2005. Phenolic Compounds and Antioxidant Activity of Sorghum Grains of Varying Genotypes. J. Agri. Food Chem., 53: 6813-6818.

Garcia, E., Barret, D.M. 2002. Preservative treatments for fresh-cut fruits and vegetables. In: Fresh-Cut Fruits and Vegetable: Science, Technology and Market. (Lamikanra, O., Ed.). CRC Press Inc., Boca Raton, FL, USA. 267303.

Garrett, H. 2002. Fresh-cut Produce: Tracks and Trends. In: Lamikanra $\mathrm{O}$ (ed.). Fresh-cut Fruits and Vegetables: Science, Technology, and Market. CRC Press, Boca Raton, 1-10.

Gawlik-Dziki, U., Złotek, U., \& Swieca, M. 2007. Characterization of polyphenol oxidase from butter lettuce (Luctuca sativa var. capitata L.). Food Chem., 107: 129-135.

Gorny, J.R. 2003. New opportunities for fresh-cut apples. Fresh Cut, 11: 14-15.

Gorny, J.R., Hess-pierce, B., Cifuentes, R.A., Kader, A.A. 2002. Quality changes in fresh-cut pear slices as affected by controlled atmospheres and chemical preservatives.
Postharvest Biol. Technol., 24: 271278.

Gurbuz, G., Lee, C.Y. 1997. Colour of minimally processed potatoes as affected bymodified atmosphere packaging and antibrowning agents. $J$. Food Sci., 62: 572-576.

Hodzic, Z., Pasalic, H., Memisevic, A., Srabovic, M., Saletovic M., \& Poljakovic, M. 2009. The influence of total phenols content on antioxidant capacity in the whole grain extracts. European of J. Scientific Res., 28: 471-477.

Jeong, L., Jin, J., Kwang, M., \& Kee, P. 2008. Effects of Anti-Browning Agents on Polyphenoloxidase Activity and Total Phenolics as Related to Browning of Fresh-Cut 'Fuji' Apple. Asian Food J., 15: 79-87.

Jiang, Y., Duan, X., Joyce, D., Zhang, Z., \& $\mathrm{Li}$ J. 2004. Advances in understanding of enzymatic browning in harvest litchi fruit. Food Chem., 88: 443-446.

Kavrayan, D., Aydemir, T. 2001. Partial purification and characterization of polyphenol oxidase from peppermint (Mentha piperita). Food Chem., 74: 147-54.

Klein, B.P. 1987. Relationship of harvest date, storage conditions, and fruit characteristics to bruise susceptibility of apple. J. American Soc. Horticulture Sci., 112: 113-116.

Lee, C.Y. 1999. "Enzymatic Browning Reaction," In: F. J. Francis, Ed., Encyclopedia of food science and technology (2 ${ }^{\text {nd }}$ Edition). Wiley, New York, 494-515.

Lee, C.Y., Kagan, V., Jaworski, A.W., Brown, S.K. 1999. Enzymatic browning and relation to phenolic compounds and Polyphenoloxidase activity among various peach 
cultivars. J. Agri. Food Chem., 38: 99101.

Lee, M.K., Park, I. 2007. Studies on inhibition of enzymatic browning in some foods by Du-Zhong (Eucommia uimoides Oliver) leaf extract. Food Chem., 114: 154-163.

Lee, Y., Parka, J., Lee, Y., Choia, Y. 2003. Extending shelf-life of minimally processed apples with edible coatings and antibrowning agents. Lebensmittel-Wissenschaft undTechnologie, 36: 323-329.

Loganathan, K.J., Hemalatha, M., Gunasundari, D., Shenbhagaraman, R., Kaviyarasan, V. 2011. Antioxidant activity of hot water soluble fraction from Agaricus heterocystis and its effect on apple browning. American $J$. Food Agri., 23: 381-386.

Lu, C., Toivonen, P.A. 2000. Effect of 1 and $100 \mathrm{kPa} \mathrm{O} 2$ atmospheric pretreatments of whole 'Spartan' apples on subsequent quality and shelf life of slices stored in modified atmosphere packages. Postharvest Biol. Technol., 18: 99-107.

Lu, S., Luo, Y., Turner, E., Feng, H. 2007. Efficacy of sodium chlorite as an inhibitor of enzymatic browning in apple slices. Food Chem., 104: 824829.

Martìn-belloso, O., Soliva-fortuny, R., \& Oms-oliu, G. 2006. Fresh-cut fruits. In: Handbook of Fruits and Fruit Processing. (Hui, Y. H., Ed.). Blackwell Publishing Ltd., Oxford, UK. 129-144.

Martinez, M.V., Whitaker, J.R. 1995. The biochemistry and control of enzymatic browning. Trends in Food Sci. Technol., 6: 195-200.

Moline, H. E., Buta, J.G., Newman, I.M. 1999. Prevention of browning of banana slices using natural products and their derivatives. J. Food Quality, 22: 499-511.

Monslave-Gonzalez, A., Barbosa-Cnovas, G.V., Cavallieri, R.P., McEvily A.J., \& Iyengar, R. 1993. Control of browning during storage of apple slices by combed methods. 4Hexylresorcinol as an anti-browning agent. J. Food Sci., 58: 797-800.

Munoz, O., Sepulveda, M., Schwaerz, M. 2004. Effects of enzymatic treatment on anthocyanin pigments from grapes skin from Chilean wine. Food Chem., 87: 487- 490.

Murata, M., Tsurutani, M., Tomita, M., Homma, S., Kaneko, K. 1995. Relationship between apple ripening and browning: changes in polyphenol content and polyphenol oxidase. $J$. Agri. Food Chem., 43: 1115-1121.

Pizzocaro, F., Torreggiani, D., Gilardi, G. 1993. Inhibition of apple polyphenol oxidase (PPO) by ascorbic acid, citric acid and sodium chloride. J. Food Processing and Preservation, 17: 2130.

Ponting, J.D., Jackson, R., Watters, G. 1972. Refrigerated apple slices: preservative effects of ascorbic acid, calcium and sulfites. J. Food Sci., 37: 434-435.

Roble, C., Gormley, T.R., Butler, F. 2009. Efficacy of Natureseal ${ }^{\circledR}$ AS1 browning inhibitor in fresh-cut fruit salads applications, with emphasis on apple wedges. J. Horticultural Sci. Biotechnol., 15: 62-67.

Rocha, A.M.C.N., Brochado, C.M., Morais, A.M.M.B. 1998. Influence of chemical treatment on quality of cut apple. $J$. Food Quality, 21: 13-28.

Rojas-Grau, M.A., Soliva-Fortuny, R., Martin-Belloso, O. 2008. Effect of natural antibrowning agents on color and related enzymes in fresh-cut 'Fuji' apples as an alternative to the use of 
ascorbic acid. J. Food Sci., 73: 267272.

Rolle, R.S., Chism, G.W. 1987. Physiological consequences of minimallyprocessed fruits and vegetables. J. Food Quality, 10: 157177.

Rupasinghe, H.P.V., Murr, D.P., Deell, J.R., Odumeru, J. 2005. Influence of 1methylcyclopropene and Natureseal on the quality of fresh-cut 'Empire' and 'Crispin' apples. J. Food Quality, 28: 289-307.

Sapers, G.M. 1993. Browning of foods: Control by sulfites, antioxidants, and other means. Scientific status summary. Food Technol., 47: 75-84.

Shapton, D.A., Shapton, N.F. 1998. Principles and Practices for the Safe Processing of Foods. Woodhead Publishing Ltd., Cambridge, UK. 299302.

Son, S.M., Moon, K.D., and Lee, C.Y. 1999. Antibrowning capacity of oxalic acid and its application in apple processing. Proceedings of the $10^{\text {th }}$ IUFoST, October 3-8, Sydney, Australia, 124.
Son, S.M., Moon, K.D., Lee, C.Y. 2001. Inhibitory effects of various antibrowning agents on apple slices. Food Chem., 73: 23-30.

Suttirak, W., Supranee, M. 2010. Potential Application of Ascorbic Acid, Citric Acid and Oxalic Acid for Browning Inhibition in Fresh-Cut Fruits and Vegetables-mini review. Walailak $J$. Sci. Technol., 7: 5-14.

Toivonen, P.M.A. 2008. Influence of harvest maturity on cut-edge browning of 'Granny Smith' fresh apple slices treated with anti-browning solution after cutting. Food Sci. Technol., 41: 1607-1609.

Vamos-Vigyazo, L., Gajzago, I., NadudvariMarkus, V., Mihalyi, K. 1976. Studies into the enzymic browning and the polyphenol oxidase complex of apple cultivars. Confructa, 21: 24- 35.

Wrolstad, R.E. 1976. Color and Pigment Analyses in Fruit Products. Station Bulletin No. 624. Agricultural Experiment Station, Oregon State University, Corvallis, OR.

\section{How to cite this article:}

Maryam A.S. Abubakr. 2016. Antibrowning Activity of Bioactive Peptides from Lab-Cultured Skim Milk Hydrolysate. Int.J.Curr.Microbiol.App.Sci. 5(10): 212-228.

doi: http://dx.doi.org/10.20546/ijcmas.2016.510.023 